\title{
Transfer of heavy metals to leafy vegetables in Gazipur textile area
}

\author{
M. Begum ${ }^{1 *}$, M. N. Gani ${ }^{2}$ and M. D. Alam ${ }^{3}$ \\ ${ }^{I}$ Soil and Environmental Sciences, University of Barisal, Bangladesh \\ ${ }^{2}$ Fiber Quality Improvement Division, Bangladesh Jute Research Institute, Dhaka, Bangladesh \\ ${ }^{3}$ Department of Soil, Water and Environment, University of Dhaka, Bangladesh
}

Received: 10 January 2021

Revised: 06 June 2021

Accepted: 28 June 2021

DOI: https://doi.org/10.3329/bjsir.v56i3.55963

\begin{abstract}
Heavy metal pollution of soils is a major concern today because contamination of food chain considered as one of the major environmental pathways of human exposure leading to potential health risk.A pot experiment was carried out to investigate the transfer of $\mathrm{Zn}, \mathrm{Cu}, \mathrm{Ni}, \mathrm{Fe}, \mathrm{Cd}, \mathrm{Cr}, \mathrm{Pb}$ and Mn from non-contaminated and contaminated soils to jute leaves vegetable plant and to evaluate their associated health risk in the local population. The mean concentration of the heavy metals in jute leaves vegetable plants followed a decreasing order of $\mathrm{Fe}>\mathrm{Zn}>\mathrm{Mn}>\mathrm{Cu}>\mathrm{Cr}>\mathrm{Pb}>\mathrm{Cd}>\mathrm{Ni}$. Among the all heavy metals the highest transfer factor (TF) values was found for $\mathrm{Cu}$ (77.50-34.95) and the lowest TF value was observed for $\mathrm{Ni}(0-0.001)$ in jute leaves vegetables plant. The daily intake of metals (DIM) for a person through ingestion of jute leaves were in order of $\mathrm{Fe}>\mathrm{Mn}>\mathrm{Zn}>\mathrm{Cu}>\mathrm{Cr}>\mathrm{Pb}>\mathrm{Ni}>\mathrm{Cd}$. The values of health risk index (HRI) for the heavy metals were less than 1, therefore, no significant health risk is anticipated for the local consumers through ingestion of jute leaves.
\end{abstract}

Keywords: Heavy metals; Jute leaves; Contaminated soils; Daily intake; Health risk

\section{Introduction}

Heavy metals are conventionally defined as elements with metallic properties and an atomic number $>20$. The most common heavy metal contaminants are $\mathrm{Cd}, \mathrm{Cr}, \mathrm{Cu}, \mathrm{Hg}, \mathrm{Pb}$, and $\mathrm{Zn}$. Metals are natural components in soil (Lasat, 2000). Some of these metals are micronutrients necessary for plant growth, such as $\mathrm{Zn}, \mathrm{Cu}, \mathrm{Mn}, \mathrm{Ni}$, and $\mathrm{Co}$, while others have unknown biological function, such as $\mathrm{Cd}, \mathrm{Pb}$, and $\mathrm{Hg}$ (Gaur and Adholeya, 2004). Uptake of heavy metals by plants from soils at high concentrations may result in a great health risk taking into consideration food-chain implications. Utilization of food crops contaminated with heavy metals is a major food chain route for human exposure. The food plants whose examination system is based on exhaustive and continuous cultivation have great capacity of extracting elements from soils. The cultivation of such plants in contaminated soil represents a potential risk since the vegetal tissues can accumulate heavy metals (Jordao et al., 2006). Heavy metals become toxic when they are not metabolized by the body and accumulate in the soft tissues (Sobha et al., 2007). Chronic level ingestion of toxic metals has undesirable impacts on humans and the associated harmful impacts become perceptible only after several years of exposure (Khan et al., 2008). In Bangladesh, textile industrial wastes and effluents are being discharged at random without treatments directly to soil, canals, and rivers. They contain heavy metals like $\mathrm{Cu}, \mathrm{Zn}, \mathrm{Pb}, \mathrm{Cr}, \mathrm{Cd}$, $\mathrm{As}, \mathrm{Hg}, \mathrm{Mn}$, and Fe. Some of them are toxic to plants and some others to both plants and animals. 
They pollute our soils and natural water systems as well as ground water endangering human health, aquatic lives, and crop production (Begum et al., 2011). Vegetables are an important part of human's diet and sources of important nutrients like protein, vitamins, minerals, fiber etc. (Arai, 2002). Heavy metal accumulation in plants depends upon plant species, soil properties and the efficiency of different plants in absorbing metals, which is evaluated by either plant uptake or soil-to plant transfer factors of the metals (Rattan et al., 2005). It is necessary to obtain a better understanding about heavy metals accumulation in vegetables and agricultural soils. Consequently, the present study was aimed to evaluate the concentration of different heavy metals in post-harvest non-contaminated and contaminated soils of Gazipur and jute leaves vegetables grown on those soils.

\section{Material and methods}

\section{Study site description}

Gazipur district is located between $23^{\circ} 53^{\prime}$ and $24^{\circ} 21^{\prime}$ north latitudes and between 90 $09^{\prime}$ and 92 $39^{\prime}$ east longitudes (website 1). It is a district under Dhaka division of Bangladesh where most of the textile industries are located.The total area of Gazipur district is $1806.36 \mathrm{Sq} \mathrm{Km}$. The total population of Gazipur district is $34,03,912$, population density is $1884 / \mathrm{Sq}$ $\mathrm{Km}$ and annual growth rate is 5.21\%. Major rivers of Gazipur are Lablong, Brahmaputra, Paruli, Turag, Suti, Goali, Banar, Balu, Chelai, Bangshi, Shitalakha etc. Annual average temperature of this district is maximum $36^{\circ} \mathrm{C}$ and minimum $12.7^{\circ} \mathrm{C}$. Annual rainfall is $2376 \mathrm{~mm}$. Potato, Paddy, Jute, Oilseed, sugarcane, cotton, bamboo, jack fruit, Papaya etc. are grown here (website 2).

\section{Sampling and pre-treatment}

Soil samples were collected at the depth from $0-15 \mathrm{~cm}$ plough layer from textile industrial area of the selected district. Contaminated and non-contaminated soil samples were collected from the site. The collected soil samples were air dried, ground and screened to pass through a $2.0 \mathrm{~mm}$ sieve and then mixed thoroughly to make it a composite sample. Dry roots, grasses and other vegetative residual parts were removed from the soil. In a plastic container one $\mathrm{kg}$ of each composite sample was taken for chemical analysis.

Each earthen pot was filled up by $7 \mathrm{Kg}$ of air dried soil. Experiments were executed with four treatments; $\mathrm{T}_{1}$ $=$ non-contaminated soil $+0 \% \operatorname{RDF}($ Recommended dose of fertilizer) (Control), $\mathrm{T}_{2}=$ non-contaminated soil $+100 \% \mathrm{RDF}$, $\mathrm{T}_{3}=$ contaminated soil $+0 \% \mathrm{RDF}, \mathrm{T}_{4}=$ contaminated soil +
$100 \%$ RDF. Each treatment has three replications. The jute leaves vegetable (BJRI deshi pat shak-1) was used as test crop. Tapwater was used for irrigation of all treatments. No infection of insecticides and pesticides were observed during jute leaves growth. The crop was allowed to grow for 45 days. After harvest soil samples were collected and the separated plant parts were kept in an oven for 72 hours at $85^{\circ} \mathrm{C}$ and after constant weight, plant samples were taken out of the oven and their dry weight were taken. The dried plant samples were powdered using an electronic grinder and stored in labeled paper bags for acid extraction and heavy metal analysis.

\section{Digestion}

$0.250 \mathrm{~g}$ of sample were accurately weighed and placed in a $250 \mathrm{ml}$ Pyrex erlenmeyer flask. First, the pre-digestion step was done at room temperature for $24 \mathrm{~h}$ with $10 \mathrm{ml}$ of a $(3: 1)$ mixture of $12 \mathrm{M} \mathrm{HCl}$ and $17 \mathrm{M} \mathrm{HNO}_{3}$. Then, the suspension was digested on hotplate at $130^{\circ} \mathrm{C}$ for $15 \mathrm{~min}$. The obtained suspension was cooled until room temperature, filtered through an ashless Whatman 41 filter and, finally, diluted to $25 \mathrm{ml}$ with $0.17 \mathrm{M} \mathrm{HNO}_{3}$. The extraction was based on the ISO 11466 (1995) method.

\section{Heavy metal analysis}

Flame atomic absorption spectrophotometer was used for the analysis of the heavy metals $\mathrm{Fe}, \mathrm{Zn}, \mathrm{Mn}, \mathrm{Cu}, \mathrm{Co}, \mathrm{Ni}, \mathrm{Cd}$, Crand $\mathrm{Pb}$ (Wodaje and Abebaw 2017). Final concentrations of the metals in the soil samples were calculated using the following formula (Uwah et al., 2012):

Concentration $(\mathrm{mg} / \mathrm{kg})=\underline{\text { Concentration }(\mathrm{mg} / \mathrm{L}) \times V}$

\section{W}

where, $V=$ final volume of solution, and $W=$ initial weight of sample measured.

\section{Determination of transfer factor (TF)}

The transfer coefficient was calculated by dividing the concentration of heavy metals in vegetables by the total heavy metal concentration in the soil (Kachenko and Singh, 2006).

$$
\mathrm{TF}=\text { Cplant } / \text { Csoil }
$$

where, Cplant $=$ metal concentration in plant tissue, $\mathrm{mg} / \mathrm{kg}$ fresh weight and

Csoil $=$ metal concentration in soil, $\mathrm{mg} / \mathrm{kg}$ dry weight. 


\section{Daily intake of metals}

The average daily intake of metals (DIM) was calculated according to the following formula as used by Khan et al. (2008, 2010) and Jan et al. (2010):

$\mathrm{DIM}=\underline{\mathrm{Cm}} \times \underline{\mathrm{Cf}} \times \mathrm{IRveg}$

$\mathrm{Bw}$

Where Cm, Cf, IRveg and Bw represent the metal concentrations in vegetable $(\mathrm{mg} / \mathrm{kg})$, conversion factor $(0.085)$ for conversion of fresh to dry weight vegetable (Jan et al., 2010), ingestion rate of vegetable, and average body weight, respectively. The average daily consumption of vegetables suggested by WHO guidelines in human diet is 300 to $350 \mathrm{~g}$ per person (WHO, 1989). The mean of $325 \mathrm{~g} /$ person/day was used in calculating the average daily ingestion values in this paper. An average weight of person was considered to be 60 $\mathrm{kg}$ (WHO/FAO, 2013).

Health risk Index

$$
H R I=\frac{D I M}{R_{f} D}
$$

To estimate the chronic health risk, health risk index (HRI) for each metal through contaminated food-crop consumption was determined using the following formula (Khan et al., 2008; Jan et al., 2010).

Here, HRI, DIM, and $\mathrm{R}_{\mathrm{f}} \mathrm{D}$, represent the human health risk index, daily intake of metal, and reference dose of metal, respectively.

$\mathrm{R}_{\mathrm{f}} \mathrm{D}$ is an approximation of daily tolerable exposure to which a person is expected to have without any significant risk of harmful effects during a lifespan. $\mathrm{R} D$ for $\mathrm{Pb}, \mathrm{Zn}, \mathrm{Cu}, \mathrm{Cd}, \mathrm{Cr}$ and $\mathrm{Ni}$ is $0.004,0.3,0.04,0.0005,0.003$ and $0.02 \mathrm{mg} / \mathrm{kg} / \mathrm{day}$, respectively (WHO/FAO, 2013). $\mathrm{R}_{\mathrm{f}} \mathrm{D}$ for $\mathrm{Mn}$ and $\mathrm{Fe}$ is 0.14 and $0.7 \mathrm{mg} / \mathrm{kg} /$ day, respectively (USEPA IRIS, 2011). The exposed population is considered to experience no significant risk when HRI < 1 (Khan et al., 2008; Muhammad et al., 2011).

\section{Results and discussion}

\section{Heavy metal concentration in soils}

Total soil heavy metal concentration is commonly used to indicate the degree of soil contamination (Karaka, 2004). Loading and accumulation of heavy metals in the soil depend on different factors such as the chemical form of elements, $\mathrm{pH}$, organic matter content, texture and cation exchange capacity (CEC) of the soil (Logan and Chaney, 1983). Heavy metal content in non-contaminated and contaminated soils of Gazipur are shown in Table I. In contaminated soil heavy metals concentration were higher than non-contaminated soil. Concentration of $\mathrm{Zn}, \mathrm{Cu}, \mathrm{Ni}, \mathrm{Fe}, \mathrm{Cd}, \mathrm{Cr}, \mathrm{Pb}$ and $\mathrm{Mn}$ were 1.9 and $19.38,0.22$ and $0.82,25.84$, and 30.00, 50.12 and $118.70,0.054$ and $0.133,32.42$ and $37.72,10.21$ and 27.02, 6.05 and $13.02 \mathrm{mg} / \mathrm{kg}$ in non-contaminated and contaminated soils of Gazipur, respectively. The heavy metal contents decreased in order of $\mathrm{Fe}>\mathrm{Cr}>\mathrm{Ni}>\mathrm{Pb}>\mathrm{Mn}>\mathrm{Zn}>\mathrm{Cu}>\mathrm{Cd}$ in non-contaminatedsoil, andFe $>\mathrm{Cr}>\mathrm{Ni}>\mathrm{Pb}>\mathrm{Zn}>\mathrm{Mn}>\mathrm{Cu}>\mathrm{Cd}$ in contaminated soil.

\section{Table I. Content of heavy metal in non-contaminated and contaminated soils of Gazipur}

\begin{tabular}{ccc}
\hline $\begin{array}{c}\text { Parameters } \\
(\mathrm{mg} / \mathrm{kg})\end{array}$ & $\begin{array}{c}\text { Non -Contaminated } \\
\text { Soil of Gazipur }\end{array}$ & $\begin{array}{c}\text { Contaminated Soil of } \\
\text { Gazipur }\end{array}$ \\
\hline Zinc $(\mathrm{Zn})$ & 1.9 & 19.38 \\
Copper $(\mathrm{Cu})$ & 0.22 & 0.82 \\
Nickel $(\mathrm{Ni})$ & 25.84 & 30.00 \\
Iron $(\mathrm{Fe})$ & 50.12 & 118.70 \\
Cadmium $(\mathrm{Cd})$ & 0.054 & 0.133 \\
Chromium $(\mathrm{Cr})$ & 32.42 & 37.72 \\
Lead $(\mathrm{Pb})$ & 10.21 & 27.02 \\
Manganese $(\mathrm{Mn})$ & 6.05 & 13.02 \\
\hline
\end{tabular}

Zakir et al. (2015) found that the mean concentrations of $\mathrm{Cu}, \mathrm{Zn}, \mathrm{Pb}, \mathrm{Cd}$ and $\mathrm{Cr}$ in Gazipur soil samples were 36.19, $176.67,27.95,0.41$ and $29.21 \mathrm{mg} / \mathrm{kg}$, respectively. Islam et al. (2011) reported that at Gazipur district the dumping of waste resulted in a marked increase in the concentration of heavy metals in soils, and the measured metals varied in the order of $\mathrm{Fe}>\mathrm{Zn}>\mathrm{Pb}>\mathrm{Cu}>\mathrm{Cd}$. The mean concentrations of the selected heavy metals in the surface soil of the dumped site were $0.40,1.42,0.46,350.38$ and $0.03 \mathrm{mg} / \mathrm{kg}$ for $\mathrm{Cu}, \mathrm{Zn}, \mathrm{Pb}$, $\mathrm{Fe}$ and $\mathrm{Cd}$, respectively, while the mean concentrations of the heavy metals in the subsurface soil were $0.39,1.36,0.47$, 313.3 and $0.03 \mathrm{mg} / \mathrm{kgfor} \mathrm{Cu}, \mathrm{Zn}, \mathrm{Pb}, \mathrm{Fe}$ and $\mathrm{Cd}$, respectively.

\section{Heavy metal concentration in leafy vegetable}

Values obtained for $\mathrm{Zn}$ concentration in jute leaves plants indicated that in contaminated soil $\mathrm{Zn}$ accumulation was higher than non-contaminated soil (Table II). Highest value of $\mathrm{Zn}(65.70 \mathrm{mg} / \mathrm{kg})$ was found with $\mathrm{T}_{3}$, where in contaminated soil no fertilizer was applied. Lowest accumulation of $\mathrm{Zn}(40.70 \mathrm{mg} / \mathrm{kg})$ was observed in control 
Table II. Heavy metal concentration in jute leaves vegetable plant

\begin{tabular}{ccccccccc}
\hline & \multicolumn{7}{c}{ Heavy metal concentration $(\mathrm{mg} / \mathrm{kg})$} \\
\cline { 2 - 9 } Treatment & $\mathrm{Zn}$ & $\mathrm{Cu}$ & $\mathrm{Ni}$ & $\mathrm{Fe}$ & $\mathrm{Cd}$ & $\mathrm{Cr}$ & $\mathrm{Pb}$ & $\mathrm{Mn}$ \\
\hline $\mathrm{T}_{1}$ & 43.70 & 15.35 & $\mathrm{ND}$ & 1080.09 & 0.007 & 1.11 & 0.100 & 57.50 \\
$\mathrm{~T}_{2}$ & 46.70 & 17.05 & 0.030 & 1184.09 & 0.006 & 1.70 & 0.050 & 61.20 \\
$\mathrm{~T}_{3}$ & 65.70 & 30.46 & $\mathrm{ND}$ & 991.17 & 0.011 & 0.038 & 0.060 & 50.10 \\
$\mathrm{~T}_{4}$ & 60.70 & 28.66 & 0.030 & 976.03 & 0.010 & 0.045 & 0.047 & 51.90 \\
\hline
\end{tabular}

Table III. Transfer factor of heavy metal from soil to jute leaves vegetables

\begin{tabular}{ccccccccc}
\hline \multirow{2}{*}{ Treatment } & \multicolumn{7}{c}{ Transfer Factor (TF) } \\
\cline { 2 - 9 } & $\mathrm{Zn}$ & $\mathrm{Cu}$ & $\mathrm{Ni}$ & $\mathrm{Fe}$ & $\mathrm{Cd}$ & $\mathrm{Cr}$ & $\mathrm{Pb}$ & $\mathrm{Mn}$ \\
\hline $\mathrm{T}_{1}$ & 23.00 & 69.77 & 0 & 21.55 & 0.129 & 0.034 & 0.0097 & 9.50 \\
$\mathrm{~T}_{2}$ & 24.58 & 77.50 & 0.001 & 23.63 & 0.111 & 0.052 & 0.0048 & 10.12 \\
$\mathrm{~T}_{3}$ & 3.39 & 37.15 & 0 & 8.35 & 0.097 & 0.001 & 0.0022 & 3.85 \\
$\mathrm{~T}_{4}$ & 3.13 & 34.95 & 0.001 & 8.22 & 0.088 & 0.001 & 0.0017 & 3.99 \\
\hline
\end{tabular}

Table IV. Daily intake of heavy metals (DIM) through consumption of jute leaves

\begin{tabular}{rccrccccr}
\hline Treat. & $\mathrm{Zn}$ & $\mathrm{Cu}$ & $\mathrm{Ni}$ & $\mathrm{Fe}$ & $\mathrm{Cd}$ & $\mathrm{Cr}$ & $\mathrm{Pb}$ & $\mathrm{Mn}$ \\
\hline $\mathrm{T}_{1}$ & 0.020102 & 0.007061 & 0 & 0.496841 & $3.22 \mathrm{E}-06$ & 0.000511 & 0.000046 & 0.02645 \\
$\mathrm{~T}_{2}$ & 0.021482 & 0.007843 & $1.38 \mathrm{E}-05$ & 0.544681 & $2.76 \mathrm{E}-06$ & 0.000782 & 0.000023 & 0.028152 \\
$\mathrm{~T}_{3}$ & 0.030222 & 0.014012 & 0 & 0.455938 & $5.06 \mathrm{E}-06$ & $1.75 \mathrm{E}-05$ & $2.76 \mathrm{E}-05$ & 0.023046 \\
$\mathrm{~T}_{4}$ & 0.027922 & 0.013184 & $1.38 \mathrm{E}-05$ & 0.448974 & $4.6 \mathrm{E}-06$ & $2.07 \mathrm{E}-05$ & $2.16 \mathrm{E}-05$ & 0.023874 \\
\hline
\end{tabular}

Table V. Health risk index (HRI) for heavy metals caused by consumption of jute leaves

\begin{tabular}{ccccccccc}
\hline Treat. & $\mathrm{Zn}$ & $\mathrm{Cu}$ & $\mathrm{Ni}$ & $\mathrm{Fe}$ & $\mathrm{Cd}$ & $\mathrm{Cr}$ & $\mathrm{Pb}$ & $\mathrm{Mn}$ \\
\hline $\mathrm{T}_{1}$ & 0.067 & 0.177 & 0 & 0.710 & 0.006 & 0.170 & 0.012 & 0.189 \\
$\mathrm{~T}_{2}$ & 0.072 & 0.196 & 0.0007 & 0.778 & 0.006 & 0.261 & 0.006 & 0.201 \\
$\mathrm{~T}_{3}$ & 0.101 & 0.350 & 0 & 0.651 & 0.010 & 0.006 & 0.007 & 0.165 \\
$\mathrm{~T}_{4}$ & 0.093 & 0.330 & 0.0007 & 0.641 & 0.009 & 0.010 & 0.005 & 0.171 \\
\hline
\end{tabular}


$\left(\mathrm{T}_{1}\right)$. For $\mathrm{Zn}$ accumulation, the treatment may be arranged in order of $\mathrm{T}_{3}>\mathrm{T}_{4}>\mathrm{T}_{2}>\mathrm{T}_{1}$. Similarly, highest concentration of $\mathrm{Cu}$ in jute leaves vegetable plant observed with $\mathrm{T}_{3}$, which was $30.46 \mathrm{mg} / \mathrm{kg}$. In control $\left(\mathrm{T}_{1}\right)$ lowest $\mathrm{Cu}$ accumulation was found,which was $15.35 \mathrm{mg} / \mathrm{kg}$. For $\mathrm{Cu}$ accumulation, the treatment may be arranged in order of $\mathrm{T}_{3}>\mathrm{T}_{4}>\mathrm{T}_{2}>\mathrm{T}_{1}$. Nickel was not found with $\mathrm{T}_{1}$ and $\mathrm{T}_{3}$. And in both $\mathrm{T}_{2}$ and $\mathrm{T}_{4}$ concentration of $\mathrm{Ni}$ was $0.030 \mathrm{mg} / \mathrm{kg}$.

The highest level of $\mathrm{Fe}(1184.09 \mathrm{mg} / \mathrm{kg})$ was found with $\mathrm{T}_{2}$, where $100 \%$ fertilizer was applied in non-contaminated soil. The lowest level of $\mathrm{Fe}(976.03)$ was observed in $\mathrm{T}_{4}$, where in contaminated soil $100 \%$ fertilizer was applied. The treatment may be arranged as $\mathrm{T}_{2}>\mathrm{T}_{1}>\mathrm{T}_{3}>\mathrm{T}_{4}$ for $\mathrm{Fe}$ accumulation in jute leaves vegetable plant. Thehighestand lowest concentration of Cd 0.011 and $0.006 \mathrm{mg} / \mathrm{kg}$ in jute leaves vegetable plant were found in $\mathrm{T}_{3}$ and $\mathrm{T}_{2}$, respectively. Cr concentration in $\mathrm{T}_{2}$ $(1.70 \mathrm{mg} / \mathrm{kg})$ and $\mathrm{T}_{3}(0.038 \mathrm{mg} / \mathrm{kg})$ were highest and lowest values, respectively. $\mathrm{Pb}$ concentration was found highest with $\mathrm{T}_{1}$, which was $0.100 \mathrm{mg} / \mathrm{kg}$ in jute leaves plant. Lowest value of $\mathrm{Pb}(0.047 \mathrm{mg} / \mathrm{kg})$ was observed with $\mathrm{T}_{4}$. Manganese accumulation was found maximum $(61.20 \mathrm{mg} / \mathrm{kg})$ in $\mathrm{T}_{2}$ and minimum $(50.10 \mathrm{mg} / \mathrm{kg})$ in $\mathrm{T}_{3}$. For $\mathrm{Cd}, \mathrm{Cr}, \mathrm{Pb}$ and $\mathrm{Mn}$ accumulation the treatment may be arranged in order of $\mathrm{T}_{3}>\mathrm{T}_{4}>\mathrm{T}_{1}>\mathrm{T}_{2}, \mathrm{~T}_{2}>\mathrm{T}_{1}>\mathrm{T}_{4}>\mathrm{T}_{3}, \mathrm{~T}_{1}>\mathrm{T}_{3}>\mathrm{T}_{2}>\mathrm{T}_{4}$ and $\mathrm{T}_{2}>\mathrm{T}_{1}>\mathrm{T}_{4}>\mathrm{T}_{3}$, respectively. The findings are in consent with the following research workers:

Lübben (1993) showed large differences in the transfer of $\mathrm{Cd}, \mathrm{Zn}, \mathrm{Ni}, \mathrm{Cu}, \mathrm{Pb}$ and $\mathrm{Cr}$ from soil to plant. Natasa et al. (2015) found that the vegetables grown on contaminated soils accumulate high concentrations of heavy metals in their edible parts. The green vegetables particularly the leafy vegetables uptake higher amounts of heavy metals from the soil ecosystem. They also suggested to use adequate NPK fertilizers to minimize plant uptake of $\mathrm{Pb}$. Filipovię et al. (2012) showed accumulation and distribution of heavy metals in the plant depend on the plant species, the levels of the metals in the soil and air, the element species and bioavailability, $\mathrm{pH}$, cation exchange capacity, climacteric condition, vegetation period and multiple other factors. Jolly et al. (2013) reported that the concentration of heavy metals in soil depended mainly on the characteristics of the soil sample and the distance from the source of contamination. Uptake and accumulation of heavy metals by shoots and roots varied with heavy metal type and plant species. Jassir et al. (2005) reported that leafy vegetables grown in heavy metals contaminated soils accumulate higher amounts of metals compare to those grown in uncontaminated soils.

\section{Transfer factor of heavy metal}

The ability of a metal species to migrate from the soil into plant roots is referred to as transfer factor (TF). Transfer factor of heavy metal from soil to jute leaves vegetables are presented in Table III. Among the treatmentsthe highest transfer factor of $\mathrm{Zn}, \mathrm{Cu}, \mathrm{Ni}, \mathrm{Fe}, \mathrm{Cr}$ and $\mathrm{Mn}$ were 24.58 , $77.50,0.001,23.63,0.052$ and 10.12 , respectively found with $\mathrm{T}_{2}$, where $100 \%$ fertilizer was applied in non-contaminated soil. The lowest transfer factor of $\mathrm{Zn}, \mathrm{Cu}, \mathrm{Fe}, \mathrm{Cd}, \mathrm{Cr}$, and $\mathrm{Pb}$ were $3.13,34.95,8.22,0.088,0.001,0.0017$, respectively observed with $\mathrm{T}_{4}$, where $100 \%$ fertilizer was applied in contaminated soil. On the other hand,the highest transfer factor of $\mathrm{Cd}(0.129)$ and $\mathrm{Pb}(0.0097)$ were found with $\mathrm{T}_{1}$ (control). Among the all heavy metals the highest $\mathrm{TF}$ values were found for $\mathrm{Cu}(77.50-34.95)$ in jute leaves vegetables. The TF value for toxic element $\mathrm{Zn}(24.58$-3.13), $\mathrm{Fe}(23.63-8.22)$ and $\mathrm{Mn}(10.12-3.85)$ werealso quite high compared to Cd (0.129 - 0.088), Cr (0.052 - 0.001). Lowest $\mathrm{TF}$ value in jute leaves vegetable plant were observed for $\mathrm{Ni}(0-0.001)$. The sequence of transfer factor of heavy metals values was $\mathrm{Cu}>\mathrm{Zn}>\mathrm{Fe}>\mathrm{Mn}>\mathrm{Cd}>\mathrm{Cr}>\mathrm{Pb}>\mathrm{Ni}$. These results have similarity with the following research workers:

Natasa et al. (2015) found that the TF values differed significantly between locations and between plant species. $\mathrm{TF}$ decreased when the plants were grown in the higher soil heavy metal contamination. Saglam (2013) found that if the value of the translocation factor is higher for plants, more elements would be accumulated by them. Zhuang et al. (2009) reported the leafy vegetables are found to show a higher transfer factor.

\section{Daily intake of metals (DIM) through consumption of jute} leaves and health risk

Several human exposure pathways including food-chain, dermal-contact, and inhalation are possible routes, but oral intake is considered to be the primary pathway for exposure via the food chain (Garg et al., 2014). The daily intakes of eight metals ( $\mathrm{Zn}, \mathrm{Cu}, \mathrm{Ni}, \mathrm{Fe}, \mathrm{Cd}, \mathrm{Cr}, \mathrm{Pb}$ and $\mathrm{Mn}$ ) were estimated according to the mean concentration of each metal in jute leaves vegetable. The DIM of studied metals from the consumption of jute leaves vegetable are shown in Table IV. DIM values for all selected metals through ingestion of jute leaves were below 1 . The overall sequence of DIM for individual metals in a person through ingestion of cultivated jute leaves vegetable were in order of $\mathrm{Fe}>\mathrm{Mn}>\mathrm{Zn}>\mathrm{Cu}>$ $\mathrm{Cr}>\mathrm{Pb}>\mathrm{Ni}>\mathrm{Cd}$.

The values of HRI calculated for the selected heavy metals through consumption of jute leaves for a person are shown in Table V. Health risk indexes considering for all 
the heavy metals in jute leaves were lower than 1, which suggests that consumers may not experience potential health hazard due to intake of it. Due to jute leaves ingestion in all treatments the HRI trend were in decreasing order of $\mathrm{Fe}>\mathrm{Cu}>\mathrm{Mn}>\mathrm{Cr}>\mathrm{Zn}>\mathrm{Pb}>\mathrm{Cd}>\mathrm{Ni}$. The maximum HRI $(0.778)$ was calculated for a person through Fe consumption in $\mathrm{T}_{2}$, while the minimum (zero) was observed through $\mathrm{Ni}$ consumption in $T_{1}$ and $T_{3}$. The findings are in consent with the following research workers:

Muhammad et al. (2011) found that all of the calculated HRI values were less than one, which indicates that no significant health risk is anticipated for consumption of these tested vegetables.

\section{Heavy metals accumulation in the post-harvest soils}

After cultivation of jute leaves vegetable plant in all treatments heavy metals accumulation in the post-harvest soils decreased (Fig.1 to 8). In this experiment jute leaves vegetable plants were acted as for phytoremediation processes of heavy metals from the soils.Phytoremediation is the use of plants to clean up a contamination from soils, sediments, and water. This technology is environment friendly and potentially cost effective (Cho-Ruk et al., 2006).

In both non-contaminated and contaminated post-harvest soils $\mathrm{Zn}$ concentrationsignificantly $(P \leq 0.05)$ decreased as compared with initial values (Fig. 1). Maximum $\mathrm{Zn}$ concentration reduction were found with $T_{1}(0.66 \mathrm{mg} / \mathrm{kg})$ and $\mathrm{T}_{3}(17.55 \mathrm{mg} / \mathrm{kg})$ in non-contaminated and contaminated soil, respectively. Fertilizers were not applied in both of these treatments.

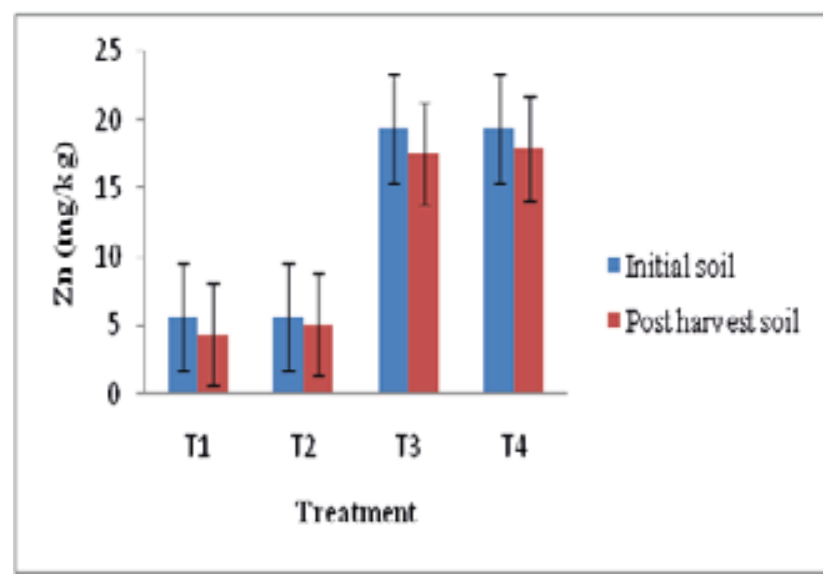

Fig. 1. Concentration of $\mathrm{Zn}$ in post-harvest soils of Gazipur
$\mathrm{Cu}$ accumulation in post-harvest soils decreased 9.09\% $\left(\mathrm{T}_{1}\right)$ and $4.55 \%\left(\mathrm{~T}_{2}\right)$ in non-contaminated soil as compared with initial value $(0.22 \mathrm{mg} / \mathrm{kg})$. And in contaminated soil $\mathrm{Cu}$ concentration reduction in post soil was comparatively low, which were $6.1 \%\left(\mathrm{~T}_{3}\right)$ and $2.44 \%\left(\mathrm{~T}_{4}\right)$ as compared with initial value $(0.82 \mathrm{mg} / \mathrm{kg})$ (Fig.2).

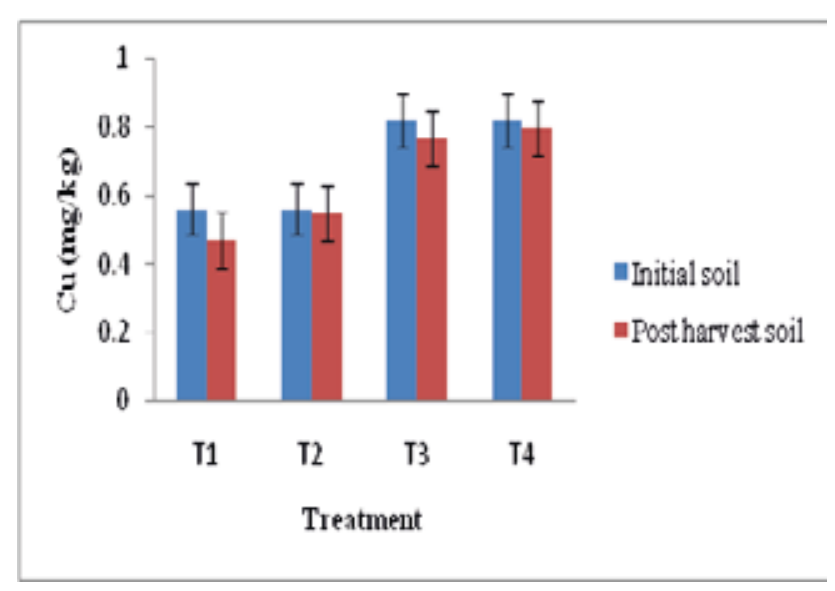

Fig. 2. Concentration of $\mathrm{Cu}$ in post-harvest soils of Gazipur

The treatments without fertilizer application in both non-contaminated and contaminated post-harvest soil $\mathrm{Ni}$ accumulation reduced more than fertilizer applied treatments (Fig. 3). Lowest concentration of $\mathrm{Ni}$ in post-harvest soils were observed in $T_{1}(20.33 \mathrm{mg} / \mathrm{kg})$ and $\mathrm{T}_{3}(29.1 \mathrm{mg} / \mathrm{kg})$ in non-contaminated and contaminated soils, respectively, which were $21.32 \%$ and $3 \%$ less as compared with initial values.

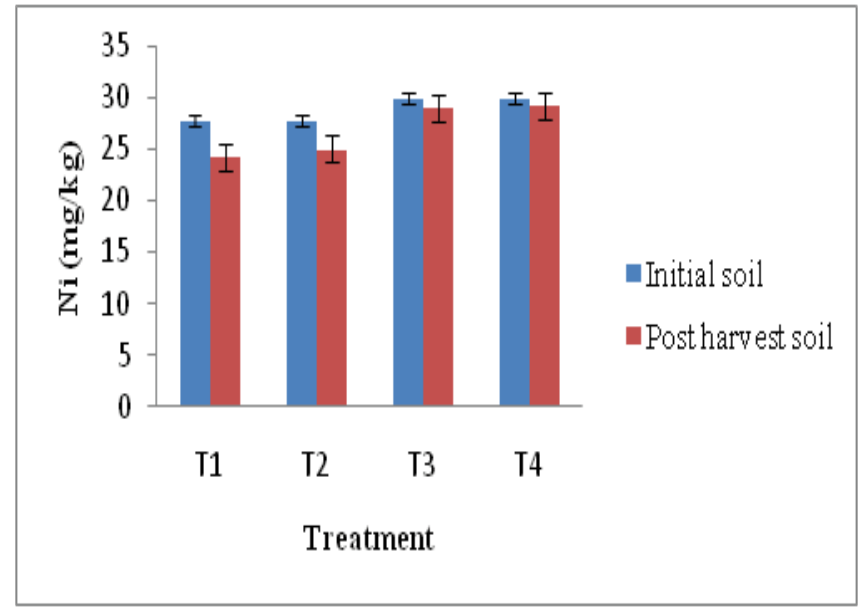

Fig. 3. Concentration of $\mathrm{Ni}$ in post-harvest soils of Gazipur 


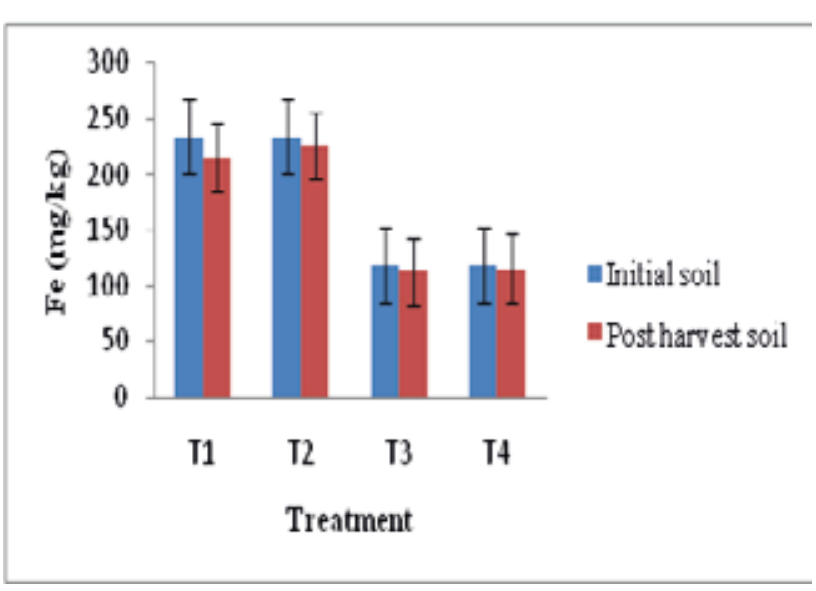

Fig. 4. Concentration of $\mathrm{Fe}$ in post-harvest soils of Gazipur

Due to no fertilizer application concentration of $\mathrm{Fe}$ in post-harvest soils reduced more than the treatments where $100 \%$ fertilizers wereused (Fig. 4). Minimum accumulation of Fe in non-contaminated post-harvest soil was $45.41 \mathrm{mg} / \mathrm{kg}$ and in contaminated soil it was $113.22 \mathrm{mg} / \mathrm{kg}$. In post-harvest soil $9.4 \%$ and $4.62 \%$ Fe concentration decreased in $T_{1}$ and $\mathrm{T}_{3}$, respectively for cultivation of jute leaves vegetables without fertilizer.

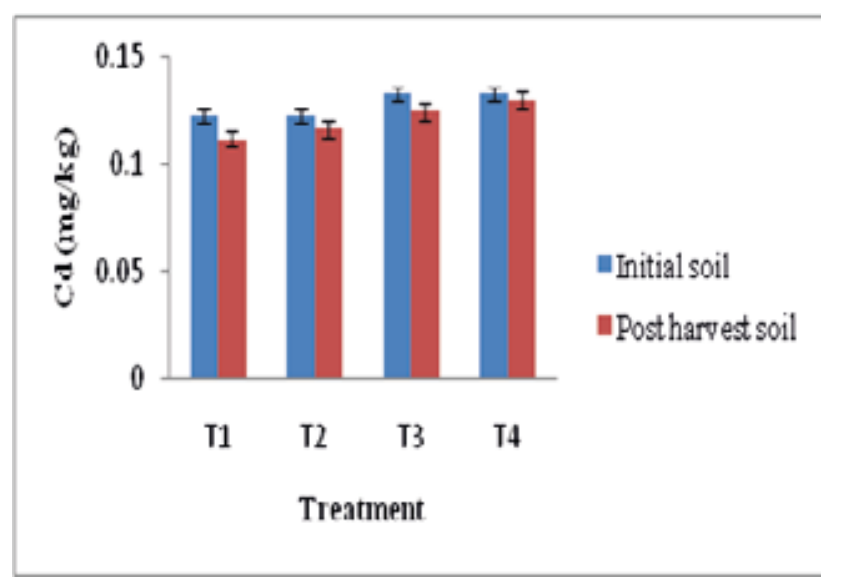

Fig. 5. Concentration of $\mathrm{Cd}$ in post-harvest soils of Gazipur

In all treatments $\mathrm{Cd}$ concentration in post-harvest soil significantly $(P \leq 0.05)$ decreased as compared with initial values (Fig.5). The lowest values of $\mathrm{Cd}$ in post-harvest non-contaminated and contaminated soils were found 0.048 $\mathrm{mg} / \mathrm{kg}$ and $0.125 \mathrm{mg} / \mathrm{kg}$, respectively. Maximum reduction of

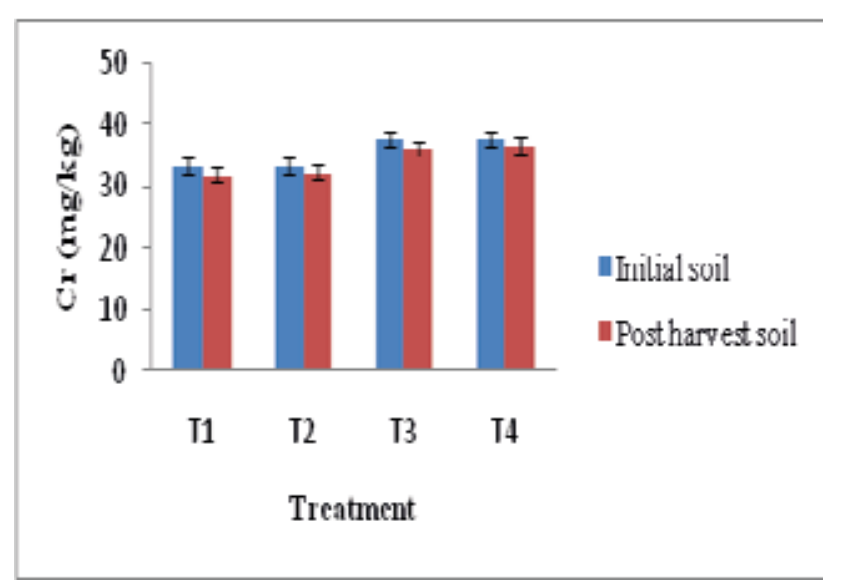

Fig. 6. Concentration of $\mathrm{Cr}$ in post-harvest soils of Gazipur

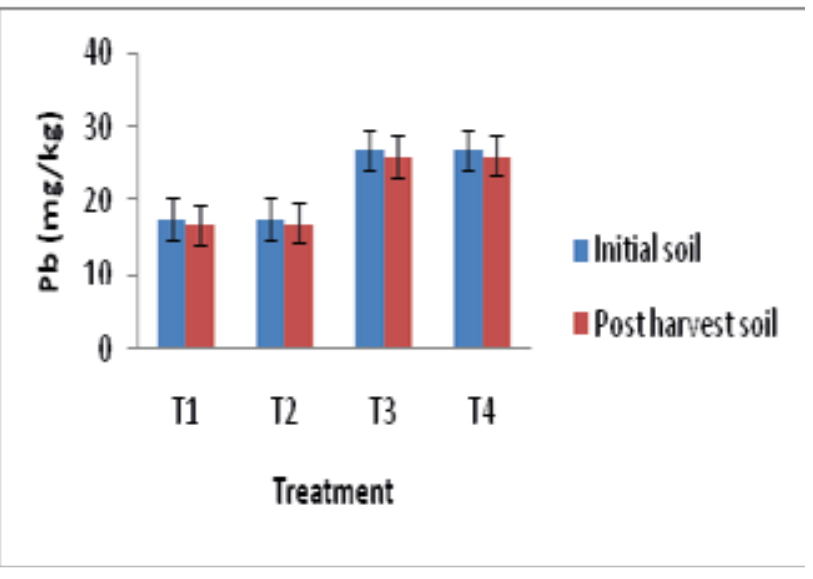

Fig. 7. Concentration of $\mathrm{Pb}$ in post-harvest soils of Gazipur

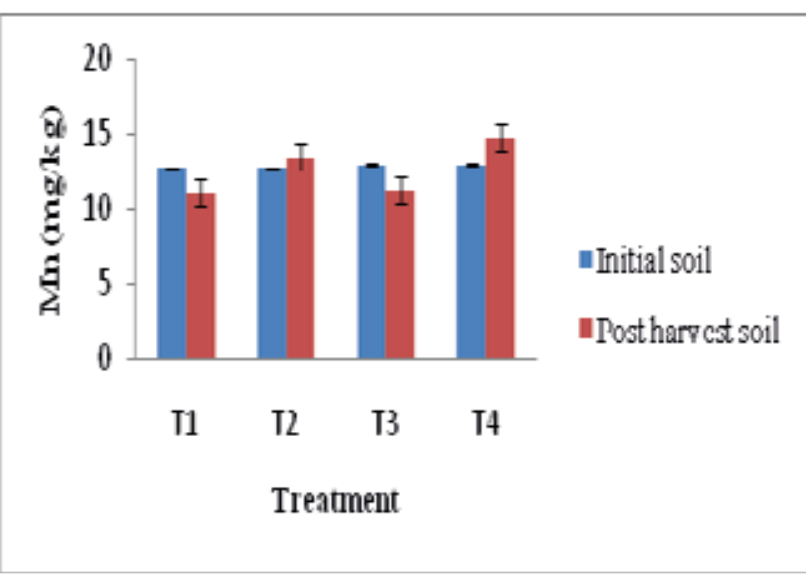

Fig. 8. Concentration of Mn in post-harvest soils of Gazipur 
Cd in post-harvest soil were found in $T_{1}$ and $T_{3}$, respectively in non-contaminated and contaminated soil.

Minimum Cr concentration in post-harvest non-contaminated and contaminated soils were observed $29.2 \mathrm{mg} / \mathrm{kg}\left(\mathrm{T}_{1}\right)$ and $36.24 \mathrm{mg} / \mathrm{kg}\left(\mathrm{T}_{3}\right)$, respectively (Fig.6). These values were $9.93 \%$ and $3.92 \%$ less as compared with initial values of non-contaminated and contaminated soils, respectively.

Lead $(\mathrm{Pb})$ concentration in post-harvest soils decreased more with $\mathrm{T}_{1}$ and $\mathrm{T}_{3}$ in non-contaminated and contaminated soil,respectively as compared with initial values. Lowest value of $\mathrm{Pb}$ in post-harvest soils were $10.02 \mathrm{mg} / \mathrm{kg}$ and $26.11 \mathrm{mg} / \mathrm{kg}$, which were $1.86 \%$ and $3.38 \%$ lower than initial values of non-contaminated and contaminated soil, respectively(Fig.7).

Application of $100 \%$ fertilizer significantly $(P \leq 0.05)$ increased but no fertilizer used significantly $(P \leq 0.05)$ decreased Mn accumulation in both post-harvest soils (Fig.8). In non-contaminated post-harvest soil $\mathrm{Mn}$ concentration $29.75 \%$ increased with $\mathrm{T}_{2}$ but with $\mathrm{T}_{1} 21.16 \%$ decreased as compared with initial value $(6.05 \mathrm{mg} / \mathrm{kg})$. Similarly in contaminated post-harvest soil $\mathrm{Mn}$ accumulation $13.44 \%$ increased with $\mathrm{T}_{4}$ but with $\mathrm{T}_{3} 13.59 \%$ decreased as compared with initial value $(13.02 \mathrm{mg} / \mathrm{kg})$. The results are consistent of the following scientists:

Wang and Greger (2006) reported that phytoextraction is considered as an environment friendly method to remove metals from contaminated soils in situ. This method can be used in much larger-scale for clean-up operations and has been applied for other heavy metals. Mwegoha (2008) found that phytoremediation can be a time-consuming process, and it may take at least several growing seasons to clean up a site. Bhatti et al. (2016) reported that use of NPK fertilizers and other agrochemicals further contaminate the soil with heavy metals. Various NPK fertilizers act as source of heavy metals such as $\mathrm{Cd}, \mathrm{As}, \mathrm{Pb}, \mathrm{Cr}, \mathrm{Ni}, \mathrm{Cu}$ etc.

\section{Conclusion}

From the above findings, it could be concluded that the concentration of Fe was highest at the study area followed by $\mathrm{Cr}>\mathrm{Ni}>\mathrm{Pb}>\mathrm{Mn}>\mathrm{Zn}>\mathrm{Cu}>\mathrm{Cd}$ in non-contaminated soil, and $\mathrm{Cr}>\mathrm{Ni}>\mathrm{Pb}>\mathrm{Zn}>\mathrm{Mn}>\mathrm{Cu}>\mathrm{Cd}$ in contaminated soil. Jute leaves vegetables grown in heavy metals contaminated soils accumulate higher amounts of metals compare to those grown in non-contaminated soils, which were lower than maximum allowable limit of FAO/WHO (2001). The sequence of the transfer factor of heavy metals for jute leaves vegetable was $\mathrm{Cu}>\mathrm{Zn}>\mathrm{Fe}>\mathrm{Mn}>\mathrm{Cd}>\mathrm{Cr}>\mathrm{Pb}>\mathrm{Ni}$. The results of this study indicated that all the HRI values of selected heavy metals were found with the safe limits
$(\mathrm{HRI}<1)$, with no significant health risk anticipated for the local consumers through ingestion of jute leaves grown in the study area.Cultivation of jute leaves vegetable also reduced the heavy metals concentration in post-harvest soils, which removed heavy metals from contaminated soils as phytoremediation. It is suggested that monitoring of heavy metals should be conducted regularly for all agricultural soils and food-crop to minimize the human health risks.

\section{Acknowledgement}

Author is extremely grateful to honorable prime minister for awarding the scholarship to carry out such a piece of valuable research work. Author also greatfully acknowledge the BJRI authority for giving the opportunity of pot experiments and using the laboratory.

\section{References}

Arai S (2002), Global view on functional foods: Asian perspectives, Brit J Nutr. 88: S139-S143. DOI: org/10.1079/BJN2002678

Begum R, Zaman M, Mondol A, Islam M and Hossain $M$ (2011), Effects of textile industrial waste water and uptake of nutrients on the yield of rice, Bang J Agric Res. 36(2): 319-331. DOI: https://doi.org/10.3329/bjar.v36i2.9260

Bhatti SS, Sambyal V and Nagpal AK (2016), Heavy metals bioaccumulation in Berseem (Trifolium alexandrinum) cultivated in areas under intensive agriculture, Punjab, India, Spri Plus. 5: 173.

Cho-Ruk K, Kurukote J, Supprung Pand Vetayasuporn S (2006), Perennial plants in the phytoremediation of lead-contaminated soils, Biotech. 5(1): 1-4.

FAO/WHO (2001), Food additives and contaminants, Codex alimentarius commission, Joint FAO/WHO Food Standards Program, ALI-NORM 01/12A. pp 1-289.

Filipovię TR, Ilię SZ and unię L (2012), The potential of different plant species for heavy metals accumulation and distribution, J FoodAgric Env. 10: 959-964.

Garg VK, Yadav P, Mor S, Singh B and Pulhani V (2014), Heavy metals bioconcentration from soil to vegetables and assessment of health risk caused by their ingestion, Bio Trace Ele Res. 157: 256-265. 
Gaur A and Adholeya A (2004), Prospects of arbuscular mycorrhizal fungi in phytoremediation of heavy metal contaminated soils, Cur Sci. 86(4): 528-534.

Islam MM, Mahmud K, Faruk O and Billah MS (2011), Textile dyeing industries in Bangladesh for sustainable development, Int J Env Sci Dev. 2: 6-16.

ISO 11466 (1995), Soil quality-Extraction of trace elements soluble in aqua regia, $1^{\text {st }}$ Ed., Published by International Organization for Standardization.

Jan FA, Ishaq M, Khan S, Ihsanullah I, Ahmad I andShakirullah M (2010), A comparative study of human health risks via consumption of food crops grown on wastewater irrigated soil (Peshawar) and relatively clean water irrigated soil (lower Dir), J Haz Mat. 179: 612-62. DOI: org/10.1016/j.jhazmat.2010.03.047

Jassir MSA, Shaker Aand Khaliq MA(2005), Deposition of heavy metals on green leafy vegetables sold on roadsides of Riyadh City, Saudi Arabia, Bull Env Cont Tox. 75: 1020-1027.

Jolly YN, Islam A and Akbar S (2013), Transfer of metals from soil to vegetables and possible health risk assessment, Spr Plus. 2: 385.

Jordao CP, Nascentes CC, Cecon PR, Fontes RLF and Pereira JL (2006), Heavy $m$ etal availability in soil amended with composted urban solid wastes, Env Mon Asses. 112: 309-326.

Kachenko AG and Singh B (2006), Heavy metals contamination in vegetables grown in urban and metal smelter contaminated sites in Australia, Wat Air Soil Poll. 169: 101-123.

Karaca A (2004), Effect or organic wastes on the extractability of cadmium, copper, nickel and zinc in soil, Geoderma. 122: 297-303. DOI: org/10.1016/j.geoderma.2004.01.016

Khan S, Cao Q, Zheng YM, Huang YZ and Zhu YG (2008), Health risks of heavy metals in contaminated soils and food crops irrigated with wastewater in Beijing, China, Env Poll. 152: 686-692. DOI: org/10.1016/j.envpol.2007.06.056

Khan S, Rehman S, Khan AZ, Khan MA and Shah MT (2010), Soil and vegetables enrichment with heavy metals from geological sources in Gilgit, northern Pakistan, Ecotox Env Safe. 73: 1820-1827. DOI: org/10.1016/j.ecoenv.2010.08.016

Lasat MM (2000), Phytoextraction of metals from contaminated soil: a review of plant/soil/metal interaction and assessment of pertinent agronomic issues, $J$ Haz Sub Res. 2(5): 1-25. DOI: org/10.4148/1090-7025.1015

Logan TJ and Chaney RL (1983), Utilization of municipal wastewater and sludge on land-metals In: Proceeding of the 1983 Workshop on utilization of municipal wastewater and sludge on land, Ed. Page et al., University of California, pp 235-326.

Lübben S (1993), Vergleichende Untersuchungen Zur Schwermetallaufnahme Verschiedener Kulturpflanzen Aus Klärschlamm Gedüngt Böden und deren Prognose durch Bodenextraktion, Ph.D. Thesis, University of Göttingen.

Muhammad S, Shah MT and Khan S (2011), Health risk assessment of heavy metals and their source apportionment in drinking water of Kohistan region, northern Pakistan, Micro Chem J. 98: 334-343. DOI: org/10.1016/j.microc.2011.03.003

Mwegoha WJS (2008), The use of phytoremediation technology for abatement soil and groundwater pollution in Tanzania: opportunities and challenges, JSus Dev Afri. 10(1): 140-156.

Nataša M, AgičR, unię L,Milenkovię L and Ilię ZS (2015), Transfer factor as indicator of heavy metals content in plants, Fres Env Bull. 24: 670-675.

Rattan RK, Datta, SP Chhonkar PK, SuribabuK and Singh AK (2005), Long-term impact of irrigation with sewage effluents on heavy metal content in soils, crops and groundwater: A case study, Agri Eco Env. 109: 310-322. doi.org/10.1016/j.agee.2005.02.025

Saglam C (2013), Heavy metal accumulation in the edible parts of some cultivated plants and media samples from a volcanic region in southern Turkey, Ekoloji. 22(86): 1-8. DOI: org/10.5053/ekoloji.2013.861

Sobha K, Poornima A, Harini P and Veeraiah K (2007), A study on biochemical changes in the fresh water fish, catlacatla (hamilton) exposed to the heavy metal toxicant cadmium chloride, Kath Uni J Sci Eng Tech. 1(4): 1-11. DOI: org/10.3126/kuset.v3i2.2890 
USEPA IRIS (US Environmental Protection Agency) (Integrated Risk Information System) (2011), Environmental Protection Agency Region I, Washington DC 20460. http://www.epa.gov/iris/. Accessed21/04/2017

Uwah EI, Gimba MS and Gwaski PA (2012), Determination of $\mathrm{Zn}, \mathrm{Mn}, \mathrm{Fe}$ and $\mathrm{Cu}$ in Spinach and Lettuce Cultivated in Potiskum, Yobe State, Nigeria, J Agri Eco Dev. 1(4): 69-74.

Wang Y and Greger M (2006), Use of iodide to enhance the phytoextraction of mercury-contaminated soil, Sci Tot Env. 368(1): 30-39. DOI: org/10.1016/j. scitotenv.2005.09.034

WHO (World Health organization) (1989), Tech. Rep, Evaluation of certain food additives and contaminants, Technical report series Geneva, 33 ${ }^{\text {rd }}$ Report of the joint FAO/WHO expert committee on food additives, Geneva, Switzerland.
WHO/FAO (2013), Tech. Rep, Guidelines for the safe use of wastewater and food stuff, Report of the joint WHO/FAO Volume 2 no. 1, World Health Organization (WHO) and Food and Agriculture Organization (FAO), Geneva, Switzerland.

Wodaje A and Abebaw A (2017), Determination of heavy metal concentration in soils used for cultivation of Allium sativum L. (garlic) in East Gojjam Zone, Amhara Region, Ethiopia. Cog Chem. 3(2): 141-9422. DOI: org/10.1080/23312009.2017.1419422

Zakir HM, Sumi SA, Sharmin S and. Mohiuddin KM (2015), Heavy metal contamination in surface soils of some industrial areas of Gazipur, Bangladesh, J Chem Bio Phy Sci. 5(2): 2191-2206.

Zhuang P, McBride MB, Xia H, Li N and Li Z (2009), Health risk from heavy metals via consumption of food crops in the vicinity of Dabaoshan mine, South China, SciTot Env. 407: 1551-1561. DOI: org/10.1016/j.scitotenv.2008.10.061 